\title{
The Market Orientation of Smallholder South African Farmers in a Disaster Context: An Input-side Perspective within a Seed Systems Approach
}

\author{
Nwafor, Christopher Ugochukwu \\ Central University of Technology, Free State, South Africa \\ manchrizzo@hotmail.com
}

\begin{abstract}
Market-orientation is widely applied to understand the expected interaction of smallholder farmers with input and output markets. Commonly used interchangeably with market participation, it is fast becoming a key milestone for attaining smallholder commercialization. This study introduces the term into the disaster resilience, seed systems and livelihoods context. Using a mixed methods approach, 120 smallholder farmers in a drought-affected district of South Africa were sampled, and information collected for analysis. The result shows that most of the farmers rely on purchased seeds and fertilizers for crop production, and on average sold $62 \%$ of their farm produce. A market orientation index (MOI) of 55\% was estimated, showing that the farmers were market oriented. The farm size, quantities of seeds and fertilizer purchased, value of crop produced, amount received from crop sales, distance to markets and access to credit were found significant in determining their market orientation. Policy interventions were made to improve access to irrigation, seed varieties and extension delivery in the area. The finding has implications for development efforts at rebuilding after a natural disaster, as well as sourcing food aid from local smallholder farmers by humanitarian actors.
\end{abstract}

Keywords: agro-input, commercialization index, disaster, fertilizer, resilience, markets, production, seeds system.

\section{Introduction}

Market orientation is undoubtedly a frequently used concept in the smallholder agriculture policy and development discussion. In sub-Sahara African countries where agrarian economies are prevalent, the transformation of smallholder farming is generally viewed as a pre-requisite for economic growth and development (Ayenew, 2016). From an agricultural point of view, market orientation among smallholder farmers denotes a production decision influenced by prevailing conditions and market signals. Seen from an input side, it is considered as how resources are allocated for the production of goods meant for the market (Gebremedhin and Jaleta, 2010; Moti et al., 2009). Commercialization among smallholder farmers has an intrinsic relationship to their market orientation, and the terms are sometimes used interchangeably (Osmani and Hossain, 2015), or couched in related terms such as commercial-oriented and less commercial-oriented (Bekele et al., 2010; Nwafor, 2015). However, the relationship between market orientation and market participation seems tenuous, though both are elements contained within the commercialization diction. While measures of market orientation determine the volume of a farmers' crop portfolio that are relatively more marketed, market participation is measured by the proportion of crop output actually sold. Following this analogy, market orientation could be described as the intent while market participation is the action, within the commercialization setting. Put another way, commercialization behavior involves adoption of market orientation as an approach at the input level, and the facilitation of market participation at the output level (Yaseen et al., 2018). Hence, the determinants of market orientation and market participation may not be the same. 
Most studies of market orientation among smallholder farmers usually adopt the output-side analysis, by examining the quantity of produce supplied to the markets as the basis for determining their commercialization status or degree of engagement with markets. It is on this basis that studies such as that by Asuming-Brempong et al. (2013) have classified commercialization among smallholder farmers into the low, medium and high groups. Particularly relevant to the discussion, a plethora of commercialization literature reviewed by Abdullah et al. (2019) underlined that commercialization involves not only the sale of output, but also product choice and input use decisions which are based on the principles of profit maximization. It further declares that commercialization occurs on both sides, either on the output-side with increased output marketed or on the input-side by increased use of production inputs. Hence, some scholars such as Gebremedhin and Jaleta (2010) in their definition of commercialization, emphasize both produce offered for sale and use of purchased inputs in the production process. However, many studies have not utilized the later component of this definition use of purchased inputs, mostly due to data limitations (Muricho et al., 2017) among other factors. It is nonetheless, assumed that input-side commercialization in most cases proceed in tandem with the degree of participation in output markets. The role of uncertainty is pronounced in agricultural activities, whereby uncertainties, occasioned by natural and man-made disasters such as prolonged drought, floods, fire, civil strife among others, leave farmers vulnerable to various risks including the loss of income and assets. These uncertainties are an important factor in the farmers' decision-making, and enters the utility framework in their preference for security amidst several risk factors.

Within the current effort of government in South Africa and existing policy objectives as well as strategy for enhancing the participation of smallholder farmers, there has been numerous interventions aimed at increasing the engagement of these farmers with markets, and in the economy generally. In implementing a policy objective aimed at commercializing smallholder farmers, such as in South Africa, the exploration of the market-orientation trend is a means for accessing the participation of smallholders in the output market (Adenegan et al., 2013). A growing trend in exploring market participation at the expense of market orientation has also been reported (Abafita et al., 2016), as commercialization is fast becoming synonymous with output market participation in the literature.

Market orientation is a prominent term driven by triple factors that include rapid population growth, high rate of urbanization and market liberalization which impact directly on farming (Kahan, 2013). These factors bring new challenges that require farmers to develop competencies for coping with the rapidly changing environment. Many farmers, especially smallholders in developing countries, struggle to make critical choices regarding their farming activities. Resulting from globalization and the dominant requirements in cash-based economies, producing food for family consumption and selling of surplus is becoming outmoded, replaced by the need to have cash for meeting the family needs- an invariable entwining of the traditional and cash economies. This requires many to become more entrepreneurial and to run their farming activities as a business. Smallholder farmers now have to walk the pathway moving from the old-style production-driven farming to a new profit-driven enterprise. Market-oriented farming is primarily concerned with making profits from regular interaction with the markets. While remaining linked to a farm household, the goals and decisions are less directly influenced by the household, and more by markets-through the price of produce and cost of inputs. 
An agenda pushing market orientation among smallholder farmers may unfortunately have negative implications for the environment, as market-driven farmers tend to place more emphasis on the attainment of increased but short-term productivity, profitability and income, which often are unsustainable. Current development thinking favor models aligned to regenerative agriculture and other conservation-linked approaches that place emphasis on reducing intensive external input usage, as well as carbon sequestration; all of which contribute to the effort to minimize the effect of climate change on the environment. Under this scenario, many have argued that insufficient consideration is often given, in a purely market-oriented environment, to the management of the natural resources base.

Market orientation studies were traditionally based on research of large firms in developed countries, with little information about small firms in developing countries (Boohene et al., 2012), and the empirical relationship involved have not been adequately captured or adapted to smallholder producers in the agricultural sector of developing or low-income economies, especially in sub-Sahara Africa (Benos et al., 2016). Among smallholder crop farmers in developing countries, the key inputs purchased include seeds and fertilizers which make up the cost of production inputs. In the event of disasters, the vulnerability and subsequent ability of farmers to recover depends on their seed security, requiring a secure seed system. Understanding local seed systems often involve implementing a seed system security assessment, and is crucial to the livelihoods of smallholder farmers.

A seed system security assessment determines the security of farmers' seed system which considers both acute stress and more chronic long-term challenges, the focus also includes broader analysis of the cropping and livelihoods system, especially focusing on vulnerability and resilience (Sperling and McGuire, 2012). It reviews the functioning of seed systems both formal and informal that farmers use, and assesses whether seed of adequate quality is available and if farmers can access it (CIAT, 2009). This approach is preferred by development agencies and relief organizations as it promotes strategic thinking around the requisite intervention. The assessment goes beyond traditional seed needs assessment, exploring the specific seed security problem while aligning response to actions that alleviate the specific challenge as well as improvements to the system. Many scholars within the field of seed systems security have reported the inadvertent harm done to existing local seed industries by blanket distribution of emergency seed aid. It is worthy to note that in the context of seed systems assessment response, not all interventions are the same. The seed security-linked response might be applicable for a range of situations that involve acute or chronic stress such as a natural disaster or man-made crisis. With the context as a background, appropriate development practice requires an exploration of the nuances and shaping response according to what actions might be feasible, as well as the prospect to lessen the challenges and seize associated opportunities.

However, the vast number of studies on farmers' market orientation have been conducted without due consideration to smallholder farmers in a disaster, relief or recovery context. Unlike many commercial farmers who protect their livelihood activity from weather-related risks using marketbased instruments such as weather-based insurance, smallholder farmers in developing countries lack access to knowledge, formal instruments and relevant structures for managing risks. Arias et al., (2013) professed that among smallholder farmers, there is little possibility for protection against the diverse risks that are commonplace in the agricultural sector. They often resort to informal riskmanagement mechanisms such as intra-household income transfers, search for off-farm 
opportunities, informal credit arrangements and reliance on available government grants and handouts. An understanding of the market orientation among smallholder farmers in a disaster context is necessary, in view of the changing weather patterns as well as erratic rainfall occasioned by a rapidly changing climate. Climate change is poised to affect local food systems and markets, and its anticipated disproportional negative consequences for smallholders has been noted. Since smallholder farmers make important contribution to food security in South Africa, and also in other developing countries, the study of their market orientation in a disaster context is essential.

This study examined how farmers in the study area engaged with markets from the input-side. It follows the view that market orientation studies need to be crop-specific within an identified geographical area or context (Osmani and Hossain, 2016). It adopted a seed system approach due to the recent prolonged drought within the Eastern Cape and Northern Cape Provinces, and examined how maize farmers in two selected communities have adapted based on existing seed systems in their communities. Maize farmers were chosen since maize is the most important and common crop cultivated by rural farmers in South Africa, both for household food security and livelihoods. The prolonged drought $(2015$ - 2019) in the western part of the Eastern Cape province was declared a disaster, as it affected more than 5500 smallholders and close to 55,000 subsistent farmers (Karoo Space, 2020). According to official figures, the drought was one of the worst in a long time, following five years of persistent poor rainfall. The foregoing therefore provided context for the setting of the study.

\section{Study objective}

The objective of the study was to determine the market orientation among smallholder maize farmers in the Mhlaba local municipality. The specific objectives were to,

- Identify specific demographic characteristics of smallholder farmers within the study area.

- Investigate the use of purchased inputs especially seeds for crop production among the smallholder farmers.

- Estimate the commercialization and market orientation indices among the smallholders.

- Determine the factors contributing to market orientation among the smallholder farmers.

\section{Methodology}

\section{Study area}

Mhlaba local municipality is part of the Amatole District of the Eastern Cape province of South Africa, where persistent drought has been reported since 2015, based on the official report of the Department of Rural Development and Agrarian Reform (DRDAR). The local municipality was created from the merger of Nkonkobe and Nxuba local councils in 2016, and has an approximate population of 151,379 residents within an area of $6358 \mathrm{~km}^{2}$. It is the largest of the six local municipalities that comprise the Amatole District, and largely rural with the administrative offices in Fort Beaufort.

\section{Sampling}

The sample population consists of smallholder farmers within the selected local municipality and were selected based on an existing list of maize farmers, compiled by the Department of Agrarian and Rural Development in the Amatole district for its Siyakhula Programme. Following a stratified, random 
sampling technique, 120 smallholder farmers from 5 communities (Alice, Bedford, Hogsback, Middeldrift and Seymore) were identified to participate in the questionnaire survey.

\section{Data collection and Analysis}

The information collected from individual farmer interviews include their seed sources; changes in normal amounts of area or seed sown if any, reasons for any changes, the farmers' assessment of seed performance; their input use, any use of new varieties and seed aid received. Also included were how much money spent on seed and other inputs. Where various crops were cultivated, the data collection included details of each crop and shown for the current season. The collected data was entered into the Seed System Security Assessment (Version 4.1) Excel template specifically prepared for automated analysis.

\section{Empirical model}

The crop input commercialization index was determined by applying the equation;

$\mathrm{HClCl}=\mathrm{a} / \mathrm{b}$

Where; $\mathrm{HClCl}$ is the household crop input commercialization index, a= value of purchased inputs, and $b=$ total value of crops produced. The crop input commercialization index indicates the extent to which a farm household participates in the input market as a buyer (Kabiti et al., 2016). Various socioeconomic variables affect farmer's engagement with markets and is often modelled to explore their effect on the level of market orientation. The functional form is given by;

$\mathrm{MOl}_{j}=f\left(X_{i}\right)$

where $\mathrm{MOI}$ is the market orientation index of a specific farmer $\mathrm{j}$, and $\mathrm{X} i$ represents the assumed socioeconomic variables affecting the level of market orientation. The regression model is hence specified as;

$\mathrm{MOI}_{i}=\beta_{0}+\beta_{1} \mathrm{X}_{1} \ldots \ldots \ldots+\beta_{\mathrm{n}} \mathrm{X}_{\mathrm{n}}+\mu_{\mathrm{i}}$

$\mathrm{MOI}=$ market orientation index; $\beta_{0} \ldots . \beta_{n}$ are the parameters to be estimated, and $X_{1} \ldots . X_{n}$ represent explanatory variables affecting level of market orientation, and the stochastic error term given by $\mu_{i}$. The explanatory variables $(X)$ included in the regression equation are age, size of farm, experience in farming, level of education, seeds purchased, fertilizer purchased, value of crop produced, access to credit, distance to market and extension visit. The model shows a linear relationship between the dependent and explanatory variables, and given in the equation below;

$\mathrm{MOI}=\beta_{0}+\beta_{\text {age }}+\beta_{\text {fsize }}+\beta_{\text {exp }}+\beta_{\text {edu }}+\beta_{\text {seeds }}+\beta_{\text {fert }}+\beta_{\text {crop }}+\beta_{\text {credit }}+\beta_{\text {ext }}+\beta_{\text {dist }}+\mu_{\mathrm{i}} \ldots \ldots$ (4)

The variables included in the equation and type including its measurement and expected direction is shown in Table 1.

Table 1: Variables included in the regression and their description 


\begin{tabular}{|l|l|l|l|}
\hline \multicolumn{1}{|c|}{ Name of variable } & \multicolumn{1}{c|}{ Type } & & Effect \\
\hline Age of farmer & Continuous & Years (yrs) & Positive \\
\hline Farm size cultivated & Continuous & Hectares (ha) & Positive \\
\hline Farming experience & Continuous & Years (yrs) & Positive \\
\hline Level of education & Continuous & Years (yrs) & Positive \\
\hline Amount of seeds purchased & Continuous & Amount (rand) & Positive \\
\hline Quantity of fertilizer purchased & Continuous & Amount (rand) & Positive \\
\hline Value of crop produced & Continuous & Amount (rand) & Positive \\
\hline Extension visits & Dummy & $1=$ Visit / 0= No visit & Positive \\
\hline Access to formal credit & Dummy & $\begin{array}{l}1=\text { has access } \\
0=\text { No access }\end{array}$ & Positive \\
\hline Distance to market & & Kilometers (Km) & Negative \\
\hline
\end{tabular}

\section{Results:}

1. Demographic traits of respondents

The relevant features of respondents from the survey is shown in Table 2 which include their gender, type of household and size of farm.

Table 2: Demographic features of survey respondents

\begin{tabular}{|c|c|c|}
\hline Description & $\mathrm{N}=120$ & Percentage \\
\hline Male & 69 & 57.5 \\
\hline Female & 51 & 42.5 \\
\hline Adult-headed household & 99 & 82.5 \\
\hline Child-headed household & 2 & 1.7 \\
\hline Granny-headed household & 19 & 15.8 \\
\hline Land size $<0.5$ ha & 26 & 21.7 \\
\hline $0.5-1$ ha & 53 & 44.2 \\
\hline$>1-2$ ha & 41 & 34.2 \\
\hline$>2$ ha & 0 & 0 \\
\hline
\end{tabular}

Source: Questionnaire survey 2019.

Among the survey respondents, approximately $57 \%$ were male and $43 \%$ were female while most of their households were headed by adults (83\%) and elderly grand-parents (16\%). The average age of respondents was 54 years, with a minimum and maximum age of 19 years and 76 years. The mean household size was 4 persons, with minimum of 2 and maximum of 7 persons in the household. Also, $23 \%$ of respondents had a farm size less than half a hectare, $44 \%$ of respondents cultivated with a farm size between half and one hectare, while approximately $34 \%$ of respondents cultivated a farm between one and two hectares. None of the respondents in the survey had a farm size greater than two hectares. Farm sizes less than two hectares are commonplace across sub-Sahara Africa as reported in Kamara et al. (2019) among others. All respondents cultivated maize during the last season, and many also planted other crops including irish potato (29\%), cabbage (21\%), sweet potato (4\%) and spinach (19\%) in their farms. Furthermore, about $96.7 \%$ of respondents purchased fertilizers while $3.3 \%$ of respondents did not purchase fertilizer during the past season. From the survey, $89.2 \%$ of respondents had planted new maize varieties during the last 5 years which were mainly purchased (97.3\%) from agro-input dealers (85\%), NGO sources (12\%) and informal sources (3\%) such as neighbors, other farmers and relatives. 
2. Estimation of purchased input (seeds and fertilizer) used for production

From the survey among respondents, the quantity of seeds used for different identified crops cultivated and the source obtained were examined. The data in Table 3 indicates that $66 \%$ of total maize seeds planted were purchased from agro-input dealers while $17 \%$ of maize seeds planted were purchased from the local market. Home saved maize seeds (own stock) comprise $9 \%$ of planted seeds and $8 \%$ of planted maize seeds were obtained from neighbors and relatives. Quantities of other crops planted during the season under review and the source obtained are also shown in Table 3.

Table 3: Seed planted in most recent season by source among respondents

\begin{tabular}{|c|c|c|c|c|c|c|c|c|c|}
\hline \multirow{3}{*}{ Crop } & \multirow{3}{*}{$\begin{array}{l}\text { Total kg } \\
\text { sowed }\end{array}$} & \multicolumn{8}{|c|}{ Quantity (Kg) and Proportion (\%) by source } \\
\hline & & \multicolumn{2}{|c|}{$\begin{array}{l}\text { Home saved } \\
\text { /own stock }\end{array}$} & \multicolumn{2}{|c|}{$\begin{array}{l}\text { Friends, } \\
\text { neighbours, } \\
\text { relatives }\end{array}$} & \multicolumn{2}{|c|}{$\begin{array}{l}\text { Local } \\
\text { market }\end{array}$} & \multicolumn{2}{|c|}{$\begin{array}{l}\text { Agro-input } \\
\text { dealer }\end{array}$} \\
\hline & & $\mathrm{Kg}$ & $\%$ & Kg & $\%$ & $\mathrm{Kg}$ & $\%$ & $\mathrm{Kg}$ & $\%$ \\
\hline Maize & 8737 & 825 & 9 & 775 & 8 & 1475 & 17 & 5662 & 66 \\
\hline Irish Potato & 1430 & 0 & 0 & 25 & 2 & 180 & 12 & 1250 & 86 \\
\hline Cabbage & 110 & 0 & 0 & 4 & 4 & 30 & 27 & 76 & 69 \\
\hline Spinach & 54 & 0 & 0 & 0 & 0 & 18 & 33 & 36 & 67 \\
\hline Sweet Potato & $65 *$ & 10 & 15 & 55 & 85 & 0 & 0 & 0 & 0 \\
\hline
\end{tabular}

Agro-input dealers supplied most of the seeds used by respondents during the season, followed by traders in the local market close to respondents. Some of the respondent-farmers planted own stock of maize seeds from the previous season or obtained from their harvest, other sources include relatives, neighbors and other farmers especially for maize seeds. Seed (planting materials) for crops such as Irish potato, cabbage and spinach were also mostly sourced from the market. Furthermore, the survey explored inputs (seed and fertilizer) used during the previous season, and quantified the amount for each crop cultivated by respondents as shown in Table 4.

Table 4: Amount spent on inputs for each cultivated crop among respondents

\begin{tabular}{|c|c|c|c|c|c|c|}
\hline \multirow{2}{*}{ Crop } & \multicolumn{5}{|c|}{ Average Spending (Rands) } \\
\cline { 2 - 7 } & $\begin{array}{c}\text { N growing } \\
\text { this crop }\end{array}$ & Neighbors & $\begin{array}{c}\text { local } \\
\text { market }\end{array}$ & input shops & All sources & $\%$ of total \\
\hline Maize & 120 & 600.00 & 1046.88 & 1912.50 & 3559.38 & 67 \\
\hline Irish Potato & 35 & 250.00 & 350.00 & 400.00 & 1000.00 & 18 \\
\hline Cabbage & 53 & 150.00 & 400.00 & 300.00 & 750 & 14 \\
\hline Total & & 1000.00 & 1796.88 & 2612.50 & 5309.38 & 100 \\
\hline
\end{tabular}

Source: Authors questionnaire survey 2019

From the Table above, $67 \%$ of the amount spent on inputs for the previous planting season was used for the maize crop. The respondents on average spent $18 \%$ of total production spend for inputs for Irish potato, while $14 \%$ of total input budget was spent for cabbage cultivation during the previous 
season. The data highlights the importance of the maize crop among respondents within the study area, and corroborates many other studies in the Southern Africa region which report the importance attached to the maize crop among smallholder farmers. Worthy of note, is that smallholder farmers in the survey did not plant only maize during the season under review, as other crops were also planted. These crops such as Irish potato, cabbages, spinach and sweet potato are used to expand the potential household food and income baskets.

\section{Crop commercialization index}

To obtain the crop input commercialization index, the survey instrument solicited information regarding the respondent's crop production values, as well as the amount received from the sale of crops. These values were then computed as presented in Table 5. Based on the data, the maximum total value of crops produced was R27,890 and a minimum of R2,675 with a mean of R12,271 among respondents.

Table 5. Values of purchased input and commercialization indices

\begin{tabular}{lccrrr}
\hline Variables & Obs. & Mean & Std Dev. & Min. & Max. \\
\hline Total value of crops produced & 120 & 12271 & 10577.5 & 2675 & 27890 \\
Amount received from crop sales & 120 & 8494 & 8607.9 & 1050 & 23950 \\
Average spend on crop inputs & 120 & 5309 & 4093.8 & 520 & 9800 \\
Output commercialization index & 120 & 0.62 & 0.32 & 0.39 & 0.85 \\
Input commercialization index & 120 & 0.29 & 0.34 & 0.17 & 0.48 \\
\hline
\end{tabular}

Source: Authors calculation from survey data 2019

There is a high differential between the maximum and minimum values, which indicate the variance among the group of smallholder farmers. This pattern is highlighted in the average spend on crop inputs, where the maximum value is R9,800 and minimum value is $R 520$ with a mean value of R5,309. Though there are differences in farm size among respondents, the range of values imply large variations in amount of inputs used between the farmers when the sizes of farms are considered. The purchased input use pattern is an important determinant of market orientation, and among respondents the maximum output commercialization index was 0.85 while the minimum value of the index was 0.32 with a mean index of 0.62 in the study area. The farmers within the study area show high levels of commercialization, as on average $62 \%$ of crops produced was sold. Among farmers with the lowest commercialization index in the area, the value of $39 \%$ is higher than the reported average commercialization index for smallholders in sub-Sahara Africa of 30\% (Abu 2015; Agwu et al. 2012). Also, all farmers from the survey purchased inputs for their crop production, which further confirms their interaction with the markets.

\section{Market orientation factor and determinants}

While both market and home consumption play central roles in production decisions among smallholder farmers, the prevalent practice allocates resources to overall farm production, rather than to individual crops for each season. Hence, the proportion of all crops sold (both cash and kind) is compared to the total value of all crops produced, and the input purchased value in calculating the 
farmers' market orientation index. The crop marketing Index and market orientation index are shown in Table 6.

Table 6: Crop Marketing and Market Orientation Indices of respondents

\begin{tabular}{|l|l|l|l|l|}
\hline Indicator & Minimum & Maximum & Mean & Std. Dev. \\
\hline Crop Marketing Index (CMI) & 0.44 & 0.89 & 0.62 & 0.33 \\
\hline Market Orientation Index (MOI) & 0.40 & 0.79 & 0.55 & 0.31 \\
\hline
\end{tabular}

Source: Authors calculations from survey data 2019.

As shown in Table 6 above, when value of crops produced by farmers is compared to amount received from crops sold in the market, including value of crop given to compensate for services obtained such as labor and transport, as well as gifts of farm produce; the crop marketing index on average is 0.62 . It indicates that within the study area, on average farmers sold $62 \%$ of their produce. To obtain market orientation index, the total production is compared to the values of produce sold in the market and inputs used for crop production during the given period. The smallholder farmers in the survey had an average market orientation index of 0.55 , with a maximum and minimum values of 0.79 and 0.40 respectively. Following the criteria set by the World Bank (2007), where smallholder farmers who sell $50 \%$ of produce are considered to be market oriented, the study respondents on average had a market orientation index of $55 \%$ and sold approximately $62 \%$ of their crops in the market. The farmers in the survey are therefore described as market-oriented since they surpass the prescribed criteria. Finally, in exploring the determinants of market orientation among smallholder farmers from this survey, different variables shown to affect market orientation were identified and included in the regression with the results presented in Table 7 .

Table 7: Estimates of the determinants of market orientation of respondents

\begin{tabular}{lllll}
\hline Variable & Coefficient & Std. Error & P-value & Marginal effect \\
\hline Age & 0.1366 & 0.1523 & 0.386 & 0.078 \\
Farm size & 0.0013 & 0.1161 & $0.004^{*}$ & 0.646 \\
Farming experience & 0.0024 & 0.0045 & 0.152 & 0.012 \\
Education & 0.0152 & 0.0531 & 0.771 & 0.531 \\
Seed purchased & 0.0313 & 0.0141 & $0.007^{*}$ & 0.030 \\
Fertilizer purchased & 0.0518 & 0.0237 & $0.024^{* *}$ & 0.012 \\
Value of crop produced & 0.0891 & 0.0051 & $0.043^{* *}$ & 0.542 \\
Crop sales amount & 1.2089 & 0.0034 & $0.001^{*}$ & 0.053 \\
Distance to market & -0.0054 & 0.0027 & $0.048^{* *}$ & 0.001 \\
Extension visit & 1.0104 & 0.2683 & 0.328 & 0.534 \\
Access to credit & -0.5851 & 0.2972 & $0.034^{* *}$ & 0.604 \\
Constant & -3.72 & 2.23 & -1.87 & 0.047 \\
Log likelihood = -36.01483 & & & & \\
LR chi2 (10) = 6.76 & & & & \\
Prob > Chi2 = 0.000 & & & & \\
$\mathrm{R}^{2}=0.081$ & & & & \\
\hline
\end{tabular}

*, ** Significant at 1\% $(p<0.01)$ and 5\% (p<0.05). Source: Authors survey 2019. 
As shown in Table 7, a number of variables were identified to contribute to the market orientation of smallholder farmers. The variables found to be significant from this study were farm size, quantity of seeds purchased, quantity of fertilizer purchased, value of crop produced, distance to market, amount received from crop sales and access to credit. Large farm size translates to more output among farmers, with a significant effect found on the value of crop sold, as well as positively influencing the farmers decision to enter the market and sell (Dlamini 2019, Zivenge and Karavina 2012). Value of crops produced has a significant positive impact on crop market participation, households with higher crop value more likely to participate in markets and also sell greater proportion of their output. Also, quantity of fertilizer purchased is associated with increased market orientation due to expected higher yields, and the resultant provision of greater output for the market. The contribution of purchased of inputs (seeds and fertilizer) to the market orientation of farmers, as shown in this result, underscores the importance of input-side market interaction to the general market orientation of smallholder farmers. The increased use of purchased inputs in crop production positively affects the transition from lower to higher levels of market orientation (Osmani and Hussain, 2015), which increases probability for market participation among smallholder farmers.

Variables not found to contribute to market orientation in this study were age, farming experience, level of education and extension visit. The findings by Adenegan et al. (2013) suggests that age had an inverse relationship with market orientation, where increase in age reduced farmers market orientation. They however found level of education to significantly contribute to market orientation among cassava farmers surveyed in Nigeria. This finding was probably due to the high number of parttime farmers in their study, indicating that many of the respondents had other formal occupation requiring education. The role of extension service in market orientation depends on the effectiveness of the service among farmers, as it has been reported with mixed results. While Abafita et al. (2016) found that extension delivery did not have significant effect on market orientation in an earlier study, Osmani and Hossain (2015) concluded that extension delivery contributed to market orientation. This difference in findings could be related to the varied forms for delivery of extension services in different countries, and among diverse group of farmers.

\section{Conclusion}

Market orientation is associated with increased probability of marketing of output among smallholder farmers, other factors remaining constant. Within the context of a prolonged drought, smallholder farmers are greatly affected and adjust their production in the face of weather uncertainties. The study found that majority of smallholder farmers in the Mdlala local municipality were male, average age of fifty-four years, with no more than two hectares of farmland. Maize was cultivated by all farmers in the area, with some also planting additional crops like Irish potato and cabbage. Seeds for planting and fertilizers were mainly purchased by farmers from available agro-input shops, and many of the farmers had planted new maize varieties during the last five years.

The study estimated average output commercialization index among the farmers to be 0.62 indicating than, averagely $62 \%$ of the crops produced by smallholder farmers in the study area were sold. Additionally, with a market orientation index of 0.55 , farmers in the area were found to be market oriented as they marketed more than $50 \%$ of their produce. Variables found to contribute to market orientation among the farmers were farm size, quantities of seeds and fertilizer purchased, value of crops produced, distance to market, amount received from crop sales and access to credit. 
The evidence suggests that smallholder farmers in the area depend on purchased inputs for their agricultural production, and this has positive implications for the local input supply sector. Furthermore, smallholder farmers in the area showed resilience notwithstanding the long exacting period of drought, as they continued to engage with and produce for the market. Policy recommendations include establishment of basic irrigation systems for the smallholder farmers in the area, provision of improved drought-tolerant maize seed varieties through the agro-input shops, as well as increased extension services to promote water conservation and improved agronomic practices.

\section{Reference}

Abafita, J., Atkinson, J. and Kim, C.S. 2016. Smallholder Commercialization in Ethiopia: Market Orientation and Participation. International Food Research Journal, 23(4): 1979-1807.

Abdullah, A., Rabbi, F., Ahamad, R., Ali, S., Chandio, A. et al. 2019. Determinants of Commercialization and its Impact on the Welfare of Smallholder Rice Farmers by using Heckmans' two-stage Approach. Journal of Saudi Society of Agricultural Sciences, Vol. 18(2): 224-233.

Adenegan, K.O., Olorunsomo, S.O. and Nwauwa, L.O. 2013. Determinants of Market orientation among Smallholder Cassava Farmers in Nigeria. Global Journal of Management and Business Research Finance, Vol. 13(6): 57-66.

Arias, P., Hallam, D., Krivonos, E. and Morrison, J. 2013. Smallholder Integration in Changing Food Markets. Food and Agriculture Organization of the United Nations. Available at: www.fao.org/3/i3292e/i3292e.pdf (Accessed on 15/11/2019).

Ayenew, H.Y. 2016. Production efficiency and Market Orientation in Food Crops in North West Ethiopia: Application of Matching Technique for Impact Assessment. PLoS One 2016, 11(7): Available online doi: 10.1371/journal.pone.0158454 (Accessed on 05/12/2019).

Asuming-Brempong, S., Anarfi, J.K., Arthur, S. and Asante, S. 2013. Determinants of commercialization of smallholder tomato and pineapple farms in Ghana. American Journal of Experimental Agriculture, 3 (3) (2013), p. 606

Bekele, A., Kassa, B., Legesse, B. and Lemma, T. 2010. Effect of Crop Commercial Orientation on Productivity of Smallholder Farmers in Drought-prone Areas of the Central Rift Valley of Ethiopia. Ethiopian Journal of Agricultural Science, 20: 16-34.

Benos, T., Kalogeras, N., Verhees, F., Sergaki, P. and Pennings, J. 2016. Cooperatives' organizational restructuring, strategic attributes and performance: the case of agri-business cooperatives in Greece. Agribusiness, 32(1): 127-150.

Boohene, R., Agyapong, D. and Asomaning, R. 2012. A micro-level analysis of the market orientation-small business financial performance nexus. American International Journal of Contemporary Research, 2(1): 31-43.

CIAT, CRS, World Vision, Care, AGRITEX and CIMMYT, 2009. Seed System Security Assessment, Zimbabwe. A study funded by the United States Agency for International Development. Office of Foreign Disaster Assistance. in July 2009 Rome: International Center for Tropical Agriculture. Available online https://pdf.usaid.gov/pdf docs/pbaaa625.pdf (Accessed 12/03/2020) 
Dlamini, L. 2019. Determinants of Commercial Orientation and the Level of Market Participation by Women Maize Farmers in Eswatini: A Case Study of the Highveld Region. SA-TIED Working Paper No. 71. UNUWIDER, IFPRI.

Gebremedhin, B. and Jaleta, M. 2010. Commercialization of Smallholders: Does market orientation Translate into Market Participation? Working Paper No. 22, 2010. International Livestock Research Institute. Nairobi, Kenya.

Kabiti, H.M., Raidimi, N.E., Pfumayarambe, T.K. and Chauke, P.K. 2016. Determinants of Agricultural Commercialization among Smallholder Farmers in Munyati Resettlement Area, Chikombe District, Zimbabwe. Journal of Human Ecology, 53(1): 10-19.

Kahan, D. 2013. Market Oriented Farming: An Overview. Food and Agriculture Organization of the United Nations, Rome. Available at www.fao.org/3/a-i3227e.pdf. (Accessed on 15/02/2020).

Kamara, A., Conte, A., Rhodes, E.R and Cooke, R.A. 2019. The Relevance of Smallholder Farming to Agricultural Growth and Development. African Journal of Food, Agriculture, Nutrition and Development, Vol. 19(1): 14043-14065.

Karoo Space, 2019. Eastern Cape Drought - Facts and Figures. Available online at https://karoospace.co.za/eastern-cape-drought-facts-and-figures/ (Accessed on 12/01/2020).

Moti, J., Berhanu G., and Hoekstra, D. 2009. Smallholder commercialization: Processes, determinants and impact. Discussion Paper No. 18. Improving Productivity and Market Success (IPMS) of Ethiopian Farmers Project, ILRI (International Livestock Research Institute), Nairobi, Kenya.

Muricho, G., Manda, D., Sule, F. and Kassie, M. 2017. Smallholder Agricultural Commercialization and Poverty: Empirical Evidence of Panel Data from Kenya. Paper prepared for presentation at the 91th Annual Conference of the Agricultural Economics Society, 24-36 April. Dublin, Ireland.

Nwafor, C.U. 2015. Prospects of Commercialization among Small-scale Potato Farmers in Bizana. Thesis submitted to the Central University of Technology, Free State, South Africa. Available at http://ir.cut.ac.za/bitstream/handle/11462/1168/Nwafor\%2C\%20Christopher\%20Ugochukwu.pdf (Accessed on 20/11/2019).

Sperling, L. and McGuire, S. 2012. Seed System Security Assessment (SSSA): An Essential Tool for Improving the Effectiveness of Agricultural Assistance. CIAT Policy Brief, Available at https://seedsystem.org/wpcontent/uploads/2014/03/policy brief SSSA Jan 2012.pdf (Accessed on 10/04/2020).

Yaseen, A., Bryceson, K. and Mungai, A. 2018. Commercialization behaviour in production agriculture: The overlooked role of market orientation. Journal of Agribusiness in Developing and Emerging Economies, Vol. 8 No. 3, pp. 579-602.

Zivenge, E. and Karavina, C. 2012. Analysis of factors influencing market channel access by communal horticulture farmers in Chinamora District, Zimbabwe. Journal of Development and Agricultural Economics, 4(6): 147-50. DOI: 10.5897/JDAE10.070. 